\title{
Improving Teaching Methods through the Development Program for Teachers' Career and Leadership
}

\author{
An In-Depth Theoretical Study
}

\author{
Endang Prahastuti ${ }^{\mathrm{a}}$, Didik Nurhadi ${ }^{\mathrm{b}}$ \\ ${ }^{a}$ Department of Industrial Technology \\ ${ }^{\mathrm{b}}$ Department of Mechanical Engineering Education \\ Universitas Negeri Malang \\ Malang, Indonesia \\ endang.prahastuti.ft@um.ac.id
}

\author{
Siti Zahro \\ Graduate School of Technological \& Vocational Education \\ National Yunlin University of Science and Technology \\ Douliou, Taiwan \\ sitizahrovivi@gmail.com
}

\begin{abstract}
A quality teaching method is instrumental in helping students attain great success. Teachers, administrators, and academic community of teachers play a key role in the process of sustaining students' interest and boosting their selfconfidence. It is important for teachers to foster professional development and leadership in order to enhance their great quality. Furthermore, based on a method of literature review, its findings were that teachers need to make significant changes with developing their professional competencies, having networking, and conducting innovative research aimed to provide the best learning for their students.
\end{abstract}

Keywords - career; leadership; teachers; teaching; professional development

\section{INTRODUCTION}

Previous research shows that the quality of teaching process is closely related to a school's success to enhance its student learning process and achievement [1-4]. Hence, considerable support for a continuous process of professional learning at schools is required for a quality learning process [5-8].

Meanwhile, organizing system supporting teachers in continuous professional learning and perfecting teaching practices are the two most important ways to promote learning and study opportunities to school students [9-11]. The result of some research shows that the effective system for supporting the enhancement of teachers' quality is the collaborative work, that is, the cycle of feedback on a systematical work enabling teachers to critically reflect their teaching practices to identify which of their works can best encourage learning and student involvement [12-14]. Besides, Hardy [15] said that the success of this system requires administrators' support for professional learning and teachers' active participation in their own learning process. Teachers will find more detailed learning formulas making it possible for this system to work effectively and help them end in success.
Subsequently, for more extensive exploration of some other research on the development of teachers' career and leadership, this work will mention basic components of the development program for professional teachers absolutely essential for their career, such as the development process stimulated by evidence-based programs and practices and approaches to avoiding problems of the development of teachers' career.

\section{METHODS}

This research method was a literature review related to teaching methods undertaken through programs of career development and teacher leadership in developed countries. More than 30 journal articles and books were reviewed to explain the development of teachers' career and leadership. Based on literature review, researchers discussed it to provide a more in-depth with an evidence-based programs and practices as a way to be applied by teachers and supported by governments in developing countries such as Indonesia.

\section{RESULTS AND DISCUSSION}

\section{A. Basic Components of the Development of Teachers Career}

Quality learning activities are defined as a set of instructions enabling students to gain the effective learning [16], which is a factor related to a school's success to enhance its student learning process and achievement [17-19]. In this instance, each school has its own uniqueness. Results of some research identified some components which can almost universally create greater opportunities for successful development programs of teachers' career and close academic community. Researchers found three detailed components of the best practice which in turn become important to ensure the growth and success of a teacher, including effective administrators and teachers' leadership, professional development of systematic work, and professional learning communities. 


\section{B. The Development of Teachers' Careers through Evidence-Based Programs and Practices}

Some research has shown a few professional development programs especially for teachers' career to develop students' learning programs. Nevertheless, according to Borko [20], at the first stage of the development of teachers' career, there are only a few programs receiving direct, empirical supports in professional development research. There are some programs for teachers' career nationally implemented in developed countries as shown in Table I.

According to some model programs shown in Table 1, it is important for teachers to understand programs and their practical forms completely. Teachers must also understand the output and evidence components as the result of the purpose fulfillment of the implemented programs. Besides, the involvement of all concerned segments is ultimately essential to systematically support and motivate teachers to get success of their career in either local or national levels.

\section{Reducing Possible Risks in the Development of Teachers' Career}

The development of teachers' professional career may be made more effective and interesting by reducing any possible risks in it. Because teachers may find ineffective ways and feel boredom during the development process, there are challenges to organize successful, interesting programs for developing teachers' professional careers and their on-going learning processes [21]. Some helpful guidelines for educators about how to reduce potential risks in the development program of professional careers will be mentioned as follows.

- Structure the time for the professional development by purpose: The time for the professional development must be deliberately set in a systematic manner [22-25]. If carried out only to maintain the time for professional learning, the professional development program will not help teachers understand how to enhance their learning practices.

- Make professional development practices always accepted: No practices, strategies, approaches, methods, or single activity of professional development will work well every time and everywhere. The professional development must be focused on learning and students, and it must actively involve all the stakeholders in collaborative actions on outlining and bettering strategic learning for local schools. Just like the nature of changes, development programs must be adopted by all teachers at all levels in their effort to adapt. Borko [20] found that development programs of teachers' professional career may run well because of specific facilitators available for students to solve problems and adapt to the effort for developing professional careers to support special needs of learning processes at schools. Having partnership with higher educational institutions or other professional organizations may help provide infrastructural support for the professional development [32].

- Remember that study is a process, not an objective: For example, there are development programs focusing more on the weight of works than on the lesson content itself, which can destroy authentic, professional learning processes and positive environment on which growth depends. WebsterWright [33] mentioned that educators need a shift in paradigm from giving and evaluating development programs of professional career to understanding and supporting authentic and professional learning, for it lies in the everyday context. Authentic and professional learning is considered perfectly appropriate for designing thoughts, a continuously occurring cycle including designing, testing, solving problems, and redesigning [34].

- Give constructive advice: Authentic and professional learning needs methods for reflection and feedback. Vega [34] mentioned that American Institutes for Research offers a webbased service called Professional Development Activity Log, helping collect longitudinal data in the establishment of professional development programs, information from teachers, skill enhancement, and changes in teachers' teaching practices. After extensive research was conducted in some developed countries, Measures of Effective Teaching Project mentioned three different measurements to provide teachers with feedback for growth: (1) class observation by fellow teachers, which may use scale validation methods such as Learning Framework or Class Assessment and Scoring System, later explained in passing on advice about learning for teaching, (2) student evaluation using Tripod survey developed by Ron Ferguson of Harvard, which measures teachers' perception on students' abilities to care for, control, clarify, face challenges, draw interest, give, and consolidate, and (3) students' learning growth based on standard tests during years. 
TABle I. Programs And Practices Based Evidence for TeAcher CAREER DeVElopment

\section{Program Name:}

Success for All [26]

Practices:

- Whole-school reform program with intensive initial training and ongoing coaching and progress monitoring

- Cooperative learning

- Common core alignment

Outcomes \& Evidence:

- A best-evidence synthesis of whole-school reform efforts found that Success for All improved math skills among elementary and high school students and improved reading skills among students.

\section{Program Name:}

National Writing Project [27]

Practices:

- Developing leadership of local teachers (teacher-consultants) who participate in summer institutes in teaching writing

- Customized in-service programs

- Continuing education and research opportunities

Outcomes \& Evidence:

- Students of teachers who participated in the National Writing Project showed improved development of ideas, organization, and stance, as compared to control classrooms, based on 16 studies conducted in seven states.

\section{Program Name:}

National Board Certification [28]

Practices:

- The National Board for Professional Teaching Standards certification assessment process includes components such as video, examples of student work, and content knowledge exercises.

- Many districts and states provide aid and/or incentives for National Board certification.

Outcomes \& Evidence:

- Research finds that the National Board certification identifies teachers who are more effective in increasing engagement, learning, and achievement and who are more likely to stay in the profession, as compared to teachers who have not achieved certification. The NBPTS supports new and struggling teachers and helps teachers assume school-based leadership roles.

\section{Program Name:}

Mentorship Programs [29-31]

Practices:

- Effective mentorship programs connect new teachers with positive, pro-social, professional mentors in the same teaching area

Outcomes \& Evidence:

- Mentorship programs can increase teacher retention, student achievement, problem-solving skills, and confidence and reduce feelings of isolation, particularly for early-career teachers.

- High engagement in the California Formative Assessment and Support System for Teachers improved teaching practices and student achievement, producing an effect size equivalent to half a year's growth.

- Build up mutual trust between administrators and learning staffs: Great leaders focus on the increase of their community's capacity, not on their limitation and shortage [35-36]. Generally, it takes three to five years for teachers to develop their skills, and changes of teachers' knowledge and practices must be greater so that they can monitor the progress of students' test results. There is a clear evidence of correlation between teachers and students that a considerable change occurs in variables related to teachers, but minor in students' learning results [37-38]. Eventually, strong leadership constitutes the main source of supports for the development of teachers' professional career at school [30].

\section{CONCLUSION}

In the academic world, teachers are expected to make significant changes related to innovative research on how students can gain the best learning process at schools. They should be empowered with knowledge and access to sources of new curriculum and technology appropriate for them. This is all highly important in the contemporary academic world.

To be a great teacher, someone is in a great need of inspiration and motivation to continuously enhance their teaching strategies and skills. It is also necessary for teachers to consistently think of how they can best teach their students, for the success of students' learning in the future depends crucially on the quality of teaching practices. Herein, such components as the effective development program of professional careers and teachers' leadership play decisive roles in stimulating growth and encouraging teachers to be more productive to develop their own skills. Some other necessary elements of this development program include creating more considerable opportunities for the development of teachers' professional career, forming tight-knit teacher learning communities, developing teachers' career through authentic-evidence-based programs and practices, and some 
guidance to help teachers reduce potentially and commonly occurring risks in establishing development programs of teachers' professional career at schools.

\section{REFERENCES}

[1] M. Meriläinen, "Factors affecting study-related burnout among Finnish university students: Teaching-learning environment, achievement motivation and the meaning of life," Quality in Higher Education. Philadelvia, PA, vol. 20, no. 3, 2014, pp. 309-329

[2] M. E. Mincu, "Teacher quality and school improvemaent: what is the role of research?," Oxford Review of Education, vol. 41, no. 2, March 2015, pp. 253-269.

[3] G. Rogers, "Learning-to-learn and learning-to-teach: the impact of disciplinary subject study on student-teachers' professional identity," Journal of Curriculum Studies, vol. 43, no. 2, February 2011, pp. 249268 ,

[4] J. Teodorović, "Classroom and school factors related to student achievement: what works for students?," School Effectiveness and School Improvement, vol. 22, no. 2, May 2011, pp. 215-236.

[5] V. Collinson, T. F. Cook, and S. Conley, "Organizational learning in schools and school systems: Improving learning, teaching, and leading," Theory into Practice, vol. 45, no. 2, August 2006, pp. 107-116.

[6] D. F. Olivier and J. B. Huffman, "Professional learning community process in the United States: Conceptualization of the process and district support for schools," Asia Pacific Journal of Education, vol. 36, no. 2, April 2016, pp. 301-317.

[7] S. Robinson and K. Summers, "An evaluation of the educational support for teachers who teach children with life-limiting illness in schools," Pastoral Care in Education, vol. 30, no. 3, April 2012, pp. 191-207.

[8] M. Thorburn and P. Allison, "Analysing attempts to support outdoor learning in Scottish schools," Journal of Curriculum Studies, vol. 45, no. 3, May 2013.pp. 418-440.

[9] L. Darling-Hammond, R. C. Wei, A. Andree, N. Richardson, and S Orphanos, Professional Learning in the Learning Profession: A Status Report on Teacher Development in the United States and Abroad. Stanford, CA: National Staff Development Council and the School Redesign Network at Stanford University, 2009

[10] V. Farnsworth and J. Higham, "Teachers who teach their practice: The modulation of hybridised professional teacher identities in work-related educational programmes in Canada," Journal of Education and Work, vol. 25, no. 4, July 2012, pp. 473-505

[11] D. Herro and C. Quigley, "Exploring teachers' perceptions of STEAM teaching through professional development: Implications for teacher educators," Professional Development in Education, vol. 43, no. 3, July 2016, pp. 1-23.

[12] J. G. Coggshall, C. Rasmussen, A. Colton, J. Milton, and C. Jacques, Generating Teaching Effectiveness: The Role of Job-Embedded Professional Learning in Teacher Evaluation. Research \& Policy Brief. US: National Comprehensive Center for Teacher Quality, 2012.

[13] E. K. Demulder and L. C. Rigsby, "Teachers' voices on reflective practice," Reflective Practice, vol. 4, no. 3, pp 267-290, August 2003.

[14] K. Ruthven, Improving the development and warranting of good practice in teaching," Cambridge Journal of Education, vol. 35, no. 3, August 2005, pp. 407-426,

[15] I. Hardy, "In support of teachers' learning: Specifying and contextualising teacher inquiry as professional practice," Asia-Pacific Journal of Teacher Education, December 2016, vol. 44, no. 1, pp 4-19.

[16] L. Darling-Hammond, A. Jaquith, and M. Hamilton, Creating a Comprehensive System for Evaluating and Supporting Effective Teaching. Stanford, California: Stanford Center for Opportunity Policy in Education, 2012.

[17] E. A. Hanushek, "The economic value of higher teacher quality," Economics of Education Review, vol. 30, no. 3, June 2011, pp. 466-479
[18] B. Nye, S. Konstantopoulos and L. V. Hedges, "How large are teacher effects?," Educational Evaluation and Policy Analysis, vol. 26, no. 3, September 2004, pp. 237-257.

[19] S. G. Rivkin, E. A. Hanushek, and J. F. Kain, "Teachers, schools, and academic achievement," Econometrica, vol. 73, no. 2, March 2005, pp. 417-458.

[20] H. Borko, "Professional development and teacher learning: Mapping the terrain," Educational Researcher, vol. 33, no. 8, November 2004, pp. 3-15.

[21] F. Hénard, and D. Roseveare, Fostering Quality Teaching in Higher Education: Policies and Practices. An IMHE Guide for Higher Education Institutions. France: OECD, 2012.

[22] T. R. Guskey, "Apply time with wisdom," Journal of Staff Development, vol. 20, no. 2, , September 1999, pp. 10-15.

[23] T. R. Guskey and K. S. Yoon, "What works in professional development?," Phi Delta Kappan, vol. 90, iss. 7, , March 2009, pp. 495500.

[24] B. F. Birman, L. Desimone, A. C. Porter, and M. S. Garet, "Designing professional development that works," Educational leadership, vol. 57, no. 8, , May 2000, pp. 28-33.

[25] M. S. Garet, A. C. Porter, L. Desimone, B. F. Birman, and K. S. Yoon, "What makes professional development effective? Results from a national sample of teachers," American Educational Research Journal, vol. 38, iss. 4, , January 2001, pp. 915-945.

[26] R. E. Slavin, C. Lake, B. Chambers, A. Cheung, and S. Davis, "Effective reading programs for the elementary grades: A best-evidence synthesis," Review of Educational Research, vol. 79, iss. 4, December 2009, pp. 1391-1466.

[27] National Writing Project Brief, Writing Project Professional Development Continues to Yield Gains in Student Writing Achievement. Berkeley, CA: University of California, 2010.

[28] NBPTS, The Bottom Line: Impact on Student Achievement and Learning. Arlington: National Board for Professional Teaching Standards, 2012.

[29] R. Ingersoll and M. Strong, "The impact of induction and mentoring programs for beginning teachers: A critical review of the research," Review of Education Research, vol. 81, iss. 2, , June 2011, pp. 201-233.

[30] S. Beltman, C. Mansfield, and A. Price, "Thriving not just surviving: A review of research on teacher resilience," Educational Research Review, vol. 6, iss. 3, , November 2011, pp. 185-207.

[31] M. Thompson, L. Goe, P. Paek, and E. Ponte, "Beginning teachers' engagement with BTSA/CFASST," ETS Research Report Series 2, vol. 2004, iss. 4, , December 2004, pp. i-70.

[32] A. Jaquith, D. Mindich, R. C. Wei, and L. Darling-Hammond, Teacher Professional Learning in the United States: Case Studies of State Policies and Strategies. Oxford, OH: Learning Forward, 2010.

[33] A. Webster-Wright, "Reframing professional development through understanding authentic professional learning," Review of Educational Research, vol. 79, iss. 2, , January 2009, pp. 702-739.

[34] V. Vega, Teacher Development Research Review: Avoiding Pitfalls. U.S: George Lucas Educational Foundation, 2015.

[35] K. Leithwood, K. S. Louis, S. Anderson, and K. Wahlstrom, How Leadership Influences Student Learning. Chicago, IL: American Educational Research Association, 2004.

[36] L. Darling-Hammond and R. Rothman, Teacher and School Leader Effectiveness: Lessons Learned from High-Performing Systems. Washington: Alliance for Excellent Education, 2011.

[37] H. C. Hill, B. Rowan, and D. L. Ball, "Effects of teachers' mathematical knowledge for teaching on student achievement," American Educational Research Journal, vol. 42, iss. 2, January 2005, pp. 371-406.

[38] E. A. Hanushek and S. G. Rivkin, "The distribution of teacher quality and implications for policy," Annual Review of Economics, vol. 4, March 2012, pp. 131-157. 